\title{
Reliability of Child Behavior Checklist and Teacher's Report Form in a Sample of Brazilian Children*
}

Confiabilidad de la Lista de chequeo de comportamiento infantil y la forma de reporte de profesores en una muestra de niños brasileros

Received: September 14th 2012 | Revised: March 27th 2014 | Accepted: August 19 $9^{\text {th }}, 2014$

\author{
GiANA BitenCOURT Frizzo ** \\ JULIANA RigON PEDRINI \\ DAIANE SILVA DE SOUZA \\ DENISE RUSCHEL BANDEIRA \\ Juliane CALlegaro Borsa
}

Universidade Federal do Rio Grande do Sul, Brazil

doi:10.11144/Javeriana.upsy14-1.rcbc

To cite this article: Frizzo, G. B., Pedrini, J. R., Souza, D. S., Bandeira, D. R., \& Borsa, J. C. (2015). Reliability of child behavior checklist and teacher's report form in a sample of Brazilian children. Universitas Psychologica, 14(1), 149-156. http://dx.doi. org/10.11144/Javeriana.upsy14-1.rcbc

* Original research article

*** E-mails: gifrizzo@gmail.com, juliana.pedrini@ ufrgs.br, ssouza.daiane@gmail.com,drbandei@ terra.com.br, juliborsa@gmail.com

\begin{abstract}
A B S T R A C T
Instruments comprising the Achenbach System of Empirically Based Assessment are widely used worldwide to assess behavior problems in children and adolescents. The aim of the present study was to assess the temporal stability of the Child Behavior Checklist (CBCL) and Teacher's Report Form (TRF), administered to parents and teachers of school-aged children, respectively. Temporal stability was assessed based on intraclass correlation coefficient (ICC). High test-retest reliability was observed for both CBCL and TRF ( $0.87-0.91$ and $0.62-0.8$ for total behavior scale, respectively). These findings suggest that both instruments remained stable over the one-year period assessment, revealing the stability of the instrument and corroborating the findings of previous international studies.

Keywords

Child Behavior Checklist; Teacher's Report Form; child behavior problems

\section{RES U MEN}

Los instrumentos que conforman el Sistema de Evaluación Empírica de Achenbach son ampliamente utilizados en todo el mundo para evaluar los problemas de conducta en niños y adolescentes. El objetivo del presente estudio fue evaluar la estabilidad temporal de la Child Behavior Checklist ( CBCL ) y el Formulario de Informe del profesor ( TRF), administrado a los padres y maestros de niños en edad escolar, respectivamente. La estabilidad temporal se evaluó con base en el coeficiente de correlación intraclase (CCI) . Una alta fiabilidad test -retest se observó tanto para el CBCL y TRF $(0,87$ 0,91 y 0,62-0,80 para la escala total del comportamiento, respectivamente) . Estos resultados sugieren que ambos instrumentos se mantuvo estable durante el período de un año evaluado, lo que sugiere la estabilidad del instrumento y corroboran los hallazgos de estudios internacionales previos. Palabras clave Child Behavior Checklist; Teacher's Report Form; problemas de conducta en niños
\end{abstract}




\section{Introduction}

Child and adolescent behaviors can be either normal or disruptive, according to the way the individual interacts with parents/classmates and in response to situations and problems that have to be dealt with (Bolsoni-Silva \& DelPrette, 2003). Disruptive behaviors or behavior problems are defined as behavioral excesses or deficits that cause harm to individuals themselves, to people relating with them (e.g., parents, relatives, teachers, classmates), and to society as a whole (when more severe manifestations are present) (Bordin et al., 2013; Bolsoni-Silva \& DelPrette, 2003; Silva, 2000).

In general, behavior problems can be classified as externalizing or internalizing. Externalizing behaviors are characterized by impulsivity, physical or verbal aggression, hostility, hyperactivity, opposition, defiance/disobedience to peer- and teacher-imposed limits, delinquent behaviors, and antisocial manifestations. Internalizing behaviors, in turn, are characterized by excessive concern/ worry, anxiety, isolating behaviors, withdrawal, sadness, shyness, insecurity, fears, symptoms that are frequently manifested as depression, social withdrawal, and anxiety disorder (Achenbach, 2001; Achenbach \& Edelbroch, 1979).

Literature has pointed a high prevalence of behavior problems in children and adolescents in several countries around the world (Alvarenga, Magalhães, \& Gomes, 2012; López-Sóler et al., 2009; Keegstra, Post, \& Goorhuis-Brouwe, 2010; Oort, Ende, Wadsworth, Verhulst, \& Achenbach, 2011; Syed, Hussein, \& Mahmud, 2007) and also in Brazil (Anselmi, Piccinini, Barros, \& Lopes, 2004; Borsa, Bandeira, \& Souza, 2011; Luiz, Gorayeb, \& Liberato, 2010). One recent study conducted by Borsa, Bandeira and Souza (2011), in which the Child Behavior Checklist (CBCL) was administered to 140 parents of students attending elementary schools in the southern Brazilian State of Rio Grande do Sul (RS), revealed that 39.3\% of the children showed clinically relevant behavior problems on the total behavior problems scale (sum of internalizing plus externalizing problems plus other instrument items) according to the responses provided by caregivers. Of the total number of children included in the sample, $41.4 \%$ showed clinically relevant internalizing behaviors (48.3\% boys and $36.3 \%$ girls) and $32.9 \%$ presented clinically relevant externalizing behaviors $(31.7 \%$ boys and $33.8 \%$ girls).

Conversely, Pedrini and Frizzo (2010) administered both the CBCL and the Teacher's Report Form (TRF) to parents and teachers of 88 children attending a public elementary school in the municipality of Porto Alegre (RS) (Achenbach, 2001). According to the respondents, $40 \%$ of the children in the sample presented clinically relevant internalizing behaviors and 34\% showed clinically relevant externalizing behaviors. Some studies point to sex differences in behavior problems. For example, a study with 1228 Brazilian parents from 6-11 year-old children showed that boys had higher scores in externalizing and total behavior problems than girls, but no difference was found between them in internalizing (Emerich, Rocha, Silvares, \& Gonçalves, 2012).

When not properly treated, behavior problems tend to persist throughout adolescence (Dekovi'c, Buist, \& Reitz, 2004; Scheneiders et al., 2003), with negative repercussions continuing into adulthood (Bongers et al., 2004; Campbell, 1995; Barke et al, 2010). With regard to temporal stability, behavior problems may be sporadic (Forgeron et al., 2010; Gauy \& Guimarães, 2006) or persistent (Ferdinand et al., 2003; Sá, Curto, Bordin, \& Paula, 2009), and their decline or replacement with more socially acceptable behaviors would be a normative developmental trend (Anselmi et al., 2007; Bolsoni-Silva, Marturano, \& Freiria, 2010; Gonçalves \& Murta, 2008; Oncü et al., 2004).

Standardized instruments are frequently used in the assessment of childhood and adolescence behavior problems (Farmer \& Aman, 2010). Checklists included in the Achenbach System of Empirically Based Assessment (ASEBA) are good examples of tools widely used to assess the presence and severity of behavior problems in children and adolescents from the 
perspective of different informants (Achenbach, 2001; Rescorla, 2005). Among the ASEBA instruments, the most frequently used are the Child Behavior Checklist (CBCL) 6/18 and the Teacher's Report Form (TRF) 6/18. These two instruments focus on the psychopathological symptoms most frequently diagnosed in childhood and adolescence and classify behavior problems as externalizing or internalizing. Based on the frequencies reported by different informants, the child is classified according to the following categories: clinical range, borderline clinical range, or non-clinical range, in both the social competence and behavior problems scales (Achenbach, 2001). A recent study conducted in 13 societies using the CBCL and TRF showed very similiar cross-informant agreement for item ratings (Rescorla et al., 2012).

International studies have confirmed the testretest reliability of $\mathrm{CBCL}$ in the measurement of behavior problems (Achenbach, Dumenci, \& Rescorla, 2003; Achenbach \& Rescorla, 2001; Achenbach, Edelbroch, \& Howell, 1987; Hofstra, Ende, \& Verhulst, 2000; Koot, Oort, Verhulst, \& Boomsma, 1997; Longstaffe, Moffatt, \& Whalen, 2000). However, few studies have assessed the reliability of the TRF (Leung et al., 2006). In particular, no studies have been conducted in Brazil to test the temporal stability of these two ASEBA scales.

In the study by Leung et al. (2006), all CBCL and TRF scales showed high test-retest reliability. Similarly, Petri (2000) assessed children with mental retardation in the United States and reported satisfactory temporal reliability results for CBCL. Finally, studies conducted by Achenbach, Edelbrock and Howell (1987) have informed that the CBCL is able to assess emotional and behavioral problems regardless of inherent developmental variances, suggesting that it can be considered a reliable instrument for the assessment of behavior problems at different stages of development.

The objective of the present study was to assess the temporal stability of the CBCL and the TRF administered to parents and teachers of schoolaged children within a one-year interval.

\section{Methods and materials}

\section{Participants}

The study sample comprised 4 teachers and 53 parents of 18 (34\%) girls and 35 (66\%) boys. 24 (45\%) parents had completed high school and 30\% completed college. Other parents had incomplete college $(11 \%)$, master degree $(6 \%)$, elementary school (6\%) or incomplete high school (2\%). Children had a mean age of 8.47 years $(\mathrm{SD}=1.51)$. Of the 53 children, 17 (32\%) attended first grade, two (4\%), second grade, 22 (46\%), third grade, and 12 (22\%) attended fourth grade ${ }^{1} .47$ (89\%) of children did not repeat any school years. All children were from a public federal school in Porto Alegre, South of Brazil. This school has students of different socioeconomic levels, since the entrance is raffled in the community.

\section{Instruments}

The CBCL and TRF instruments included in the ASEBA were used (Achenbach, 2001). A questionnaire was also used to collect sociodemographic data.

The CBCL is administered to fathers, mothers, or other caregivers with the aim of assessing behavior problems in their children. The TRF is an instrument derived from the CBCL, administered to teachers, educational consultants, and other professionals involved in the child's educational development, so that they can also provide data on the most frequent behavior problems observed. The objective of using these two versions (parents and teachers) is the possibility of focusing in contextual behaviors at home and at school (Bordin et al., 2013).

Items included in the CBCL and TRF are arranged in eight individual scales that describe

1 In Brazil, Elementary School is composed of 8 grades, and is mandatory for children 6-14 years old. The first four years have a regent teacher, which is the main teacher involved in class, so this study aimed to evaluate children's behavior problems in this context because this teacher has a whole evaluation of each child, instead of an evaluation per discipline. 
different types of behavior problems: Anxious/ Depressed, Withdrawn/Depressed, Somatic Complaints, Social Problems, Thought Problems, Attention Problems, Delinquent Behavior, and Aggressive Behavior (Achenbach, 2001; Achenbach \& Edelbroch, 1979).

The present study used the standard classification clinical range, borderline clinical range, and non-clinical range based on the frequencies informed by respondents (parents and teachers) in the internalizing and externalizing behaviors scales and also in the total behavior problems scale, i.e., the sum of all internalizing and externalizing problems, in addition to other scales and items. For the scope of the present study, and as suggested by Achenbach (2001), children classified as borderline were included in the clinical range category. The original version of the CBCL (Achenbach \& Rescorla, 2001) has shown adequate temporal stability results, with test-retest correlation coefficients of 0.87 for the total behavior problems scale.

To compare Brazilian children with US children, Rocha and Cols (2012) have applied the CBCL 6/18 in a large Brazilian general population sample (parents of 1228 non-clinical sample 6-to11-year-olds from three different regions of Brazil and 247 clinical sample 6-to-11-year-olds). Results for mean item ratings and scale internal consistencies were very similar to those found in the US. The highest alphas in both countries were found for the three scales (Internalizing, Externalizing, and Total Problems), with all alphas $\geq 0.8$. The correlation between alphas for all problem scales obtained for the referred and non-referred samples were 0.92 in Brazil, and 0.89 in the USA. The correlation between Brazil and USA was 0.93 for non-referred samples and 0.88 for referred samples. Gender patterns were comparable to those reported in other societies, but mean problem scores for non-referred Brazilian children were higher than those for USA children. These findings replicated those reported in international comparisons of CBCL 6/18 scores for 31societies, thereby providing support for the multicultural robustness of the CBCL 6/18 in Brazil (more details in Rocha et al., 2012).

\section{Procedures}

Data collection took place at two stages, with a oneyear interval between each other. At the first stage, the study was described by one of the authors to the parents of children attending early elementary grades. Each parent received an envelope containing a brief presentation of the project, an informed consent term, a form for the collection of sociodemographic data, and the CBCL. Parents who were not present at the meeting received the envelopes through their children. After one month, parents were informed via written notices that return materials would no longer be received after the end of that week. Of the total number of envelopes handed out, 88 were returned ( $88 \%$ return rate). Subsequently, teachers were contacted by the same author and asked to fill a TRF for each of the participating students.

At the second stage, one year later, the same author contacted the parents and current teachers of all participating children, following the same procedures described above. At this stage, 60 envelopes returned (69\% return rate).

The study protocol was approved by the Research Ethics Committee of the Institute of Psychology at Universidade Federal do Rio Grande do Sul (UFRGS). The Research Commission of the school where the study was conducted also approved the study before its beginning.

\section{Data analysis}

Data collected in the CBCL were analyzed using the Assessment Data Manager (ADM) software, version 7.0 (Achenbach, 2001). The following cutoff points were taken into consideration for each scale assessed by the CBCL and the TRF: $\leq 59$, non-clinical range; 60-64, borderline clinical range; $>65$, clinical range. As previously mentioned, children in the borderline clinical group were included in the clinical range category for the purpose of statistical analysis.

Descriptive statistics was used to describe the characteristics of participants and the prevalence of behavior problems. Test-retest stability of both 
CBCL and TRF was calculated using Intraclass Correlation Coefficient (ICC). Temporal stability was analyzed considering the following cutoff points suggested by Rosner (1995): ICC $<0.4=$ poor reliability; ICC $0.4-0.75=$ fair to good reliability; and ICC >0.75 = excellent reliability.

\section{Results and discussion}

Table 1 shows the ICC calculated for internalizing behaviors (Anxious/Depressed, Withdrawn/ Depressed, and Somatic Complaints scales), externalizing behaviors (Aggressive Behavior and Delinquent Behavior scales), and for the total behavior problems scale (sum of internalizing and externalizing behaviors, plus other items).

Our results suggest excellent one-year test-retest reliability for virtually all scales covering internalizing behaviors, externalizing behaviors, and the total behavior problems scale, in both the CBCL and the TRF, according to Rosner's classification (1995). The only exception was the assessment of internalizing behaviors in the TRF, which showed only fair reliability. Studies conducted with different populations have indicated similar findings. Kerr, Lunkenheimer and Olson (2007), for example, assessed 240 American children aged 3 to 5 years and observed an overall stability of CBCL and TRF results at the two measurement occasions, but only for externalizing behaviors. Similarly, the longitudinal study conducted by Ferdinand et al. (2003), which assessed the predictive value of the judgment of different informants on the presence of childhood psychopathology in 96 Dutch children aged 6 to 12 years, reported a fair stability, especially in the assessment of externalizing behaviors.

The need for convergence in the assessment of internalizing behavior problems is not a consensus, as already suggested by other authors (Bolsoni, Marturano, Pereira, \& Manfrinato, 2006; Bordin et al., 2013; Borsa \& Nunes, 2008; Ferdinand et al., 2003; Grietens et al., 2003; Pedrini \& Frizzo, 2010). It is possible that internalizing behavior problems be less persistent during child development or has fewer consequences in terms of child adjustment when compared with externalizing problems (Ferdinand et al., 2003). Externalizing behaviors, in turn, seem to present an increased temporal stability and to be at a higher risk of evolving into more severe clinical conditions during adolescence when compared with internalizing problems (Pacheco, Alvarenga, Reppold, Piccinini, \& Hutz, 2005). Moreover, externalizing behaviors are more visible to different informants, making them easier to diagnose (Emerich et al., 2012; Kerr et al., 2007). However, this aspect needs to be further assessed, as behavior problems can manifest in various ways and are perceived and assessed differently by parents and teachers.

Previous studies have indicated distinct prevalence rates for child behavior problems in Brazil and worldwide. Anselmi et al. (2004), for example, reported that about $10 \%$ of preschool children living in mid-sized cities in southern Brazil have

\section{TABLE 1.}

Cronbach's alpha, confidence interval, and reliability results for CBCL and TRF

\begin{tabular}{lccccc}
\hline Scales & $\mathrm{a}$ & $95 \% \mathrm{CI}$ & $\mathrm{ICC}$ & $\mathrm{df}_{1}$ & $\mathrm{df}_{2}$ \\
\hline CBCL (parents) & & & & & \\
Internalizing & 0.87 & $79-92$ & 0.87 & 60 & 60 \\
Externalizing & 0.89 & $81-93$ & 0.87 & 60 & 60 \\
Total & 0.91 & $85-95$ & 0.91 & 60 & 60 \\
TRF (teachers) & & & & & \\
Internalizing & 0.62 & $74-78$ & 0.62 & 52 & 52 \\
Externalizing & 0.77 & $60-86$ & 0.77 & 52 & 52 \\
Total & 0.8 & $65-88$ & 0.8 & 52 & 52 \\
\hline
\end{tabular}

$p<0.001$

Source: own work 
at least one psychiatric disorder related with behavior problems. Findings like this underscore the importance of improving our knowledge of disorders possibly affecting child development, so that new interventions can be designed to help address these problems.

\section{Final considerations}

The present study assessed the temporal stability of CBCL and TRF. Both instruments have already been adapted into different contexts and are widely used to assess behavior problems among children and adolescents, both in Brazil and internationally, with adequate psychometric properties shown for their different versions. However, in the Brazilian context, evidence coming from validity studies is still lacking.

Additional studies are warranted to provide further evidence of the validity of these instruments and to confirm their effectiveness in different contexts and populations. The present study describes the reliability of CBCL and TRF over a one-year time span. High temporal stability results were observed, in spite of the long interval elapsed between the two measurement sessions, suggesting instrument solidity and corroborating the findings of previous, international studies. Notwithstanding, it is important to emphasize that our sample was small, underscoring the need for future multicenter studies, with larger and more heterogeneous samples, in order to provide further evidence of the validity and reliability of these instruments.

\section{References}

Achenbach, T. M. (2001). Manual for the Child Behavior Checklist/6-18 and 2001 profile. Burlington: University of Vermont.

Achenbach, T. M., Dumenci, L., \& Rescorla, L. A. (2003). Are American Children's Problems Still Getting Worse? A 23-Year Comparison. Journal of Abnormal Child Psychology, 31, 1-11.

Achenbach, T. M., \& Edelbroch, C. (1979). The child behavior profile: II. Boys aged 12-16 and girls aged
6-11 and 12-16. Journal of Consulting and Clinical Psychology, v. 47, n. 2, p. 223-233, 1979.

Achenbach, T. M., Edelbroch, C., \& Howell, C. T. (1987). Empirically based assessment of the behavioral/emotional problems of 2- and 3-year-old children. Journal of Abnormal Child Psychology, 15(4), 629-650.

Alvarenga, P., Magalhães, M., \& Gomes, Q. (2012).

Relações entre práticas educativas maternas e problemas de externalização em pré-escolares. Estudos de Psicologia (Campinas), 29(1), 33-42.

Achenbach, T.M., \& Rescorla, L.A. (2001). Manual for the ASEBA school-age forms $\mathcal{E}$ profiles. Burlington: University of Vermont.

Anselmi, L., Piccininni, C. A., Barros, F. C., \& Lopes, R. S. (2004). Psychosocial determinants of behaviour problems in Brazilian preschool children. Journal of Child Psychology and Psychiatry, v. 45, p. 779-788.

Barke, E. D., Vitaro, F., Lacourse, E. F., Fontaine, N. M. G., Carbonneau, R., \& Tramblay, R. E. (2010). Testing the developmental distinctiveness of male proactive and reactive aggression with a nested longitudinal experimental intervention. Aggressive Behavior, 36(2), 127-140.

Bolsoni-Silva, A. T., \& Del Prette, A. (2003). Problemas de comportamento: um panorama da área. Revista Brasileira de Terapia Comportamental e Cognitiva, 5(2), 91-103.

Bolsoni-Silva, A. T., Marturano, E. M., \& Freiria, L. R. B. (2010). Indicativos de problemas de comportamento e de habilidades sociais em crianças: Um estudo longitudinal. Psicologia: Reflexão e Crítica, 23(3), 506-515.

Bolsoni-Silva, A., Marturano, E., Pereira, V., \& Manfrinato, J. (2006). Habilidades sociais e problemas de comportamento de pré-escolares: comparando avaliações de mães e de professoras. Psicologia: Reflexão e Crítica, 19 (3), 460-469.

Bongers, I. L., Koot, H. M., Ende, J. V. D., \& Verhulst, F. C. (2004). Developmental trajectories of externalizing behaviors in childhood and adolescence. Child Development, 75(5), 1523-1537.

Bordin, I. A., Rocha, M. M., Paula, C. S., Teixeira, M. C. T. V., Achenbach, T. M., Rescorla, L. A., \& Silvares, E. F. M. (2013). Child Behavior Checklist (CBCL),Youth Self-Report (YSR) and Teacher's 
Report Form(TRF): an overview of the development of the original and Brazilian versions. Cadernos de Saúde Pública, 29(1), 13-28.

Borsa, J. C., \& Nunes, M. L. T. (2008). Concordância parental sobre problemas de comportamento infantil através do CBCL. Paidéia, 18(40), 317-330.

Borsa, J. C., Bandeira, D. R., \& Souza, D. S. (2011). Prevalência dos problemas de comportamento em uma amostra de crianças do Rio Grande Do Sul. Psicologia: Teoria e Prática, 12(2).

Campbell, S. B. (1995). Behavior problems in preschool children: a review of recent research. Journal Child Psychology and Psychiatry, 36(1), 113-149.

Dekovi'c, M., Buist, K. L., \& Reitz, E. (2004). Stability and changes in problem behavior during adolescence: Latent growth analysis. Journal of Youth and Adolescence, 33(1), 1-12.

Emerich, D. R., da Rocha, M. M., Silvares, E. F. de M., \& Gonçalves, J. de P. (2012). Diferenças Quanto ao Gênero entre Escolares Brasileiros Avaliados pelo Inventário de Comportamentos para Crianças e Adolescentes (CBCL/6-18). Psico, 43(3), 380-387.

Farmer, C., \& Aman, M. (2009). Development of the children's scale of hostility and aggression: Reactive/proactive (C-SHARP). Research in Developmental Disabilities, 30, 1155-1167.

Ferdinand, R.F., Hoogerheide, K.N., Ende, J., Visser, J., Koot, H.M., Kasius, M.C., \& Verhulst, F.C. (2003). The role of the clinician: three-year predictive value of parents', teachers', and clinicians' judgment of childhood psychopathology. Journal of Child Psychology and Psychiatry, 44(6), 867-876.

Forgeron, P. A., King, S., Stinson, J. N., McGrath, P. J., MacDonald, A. J., \& Chambers, C. T. (2010). Social functioning and peer relationships in children and adolescents with chronic pain: a systematic review. Pain Research and Management, 15(1), 27-41.

Gauy, F.V., \& Guimarães, S. S. (2006). Triagem em saúde mental infantil. Psicologia: Teoria e Pesquisa, 22(1), 005-016.

Grietens, H., Onghena, P., Prinzie, P., Gadeyne, E., Van Assche, V., \& Ghesquière, P. (2004). Comparison of mothers', fathers', and teachers' reports on problem behavior in 5- to 6-year old children. Journal of Psychopathology and Behavioral Assessment, 2(2), 137-146.
Gonçalves, E. S., \& Murta, S. G. (2008). Avaliação dos efeitos de uma modalidade de treinamento de habilidades sociais para crianças. Psicologia: Reflexão e Crítica, 21(3), 430-436.

Hofstra, M. B., Van der Ende, J., \& Verhulst, F.C. (2000). Continuity and change of psychopathology from childhood into adulthood: a 14-year follow-up study. Journal of the American Academy of Child and Adolescent Psychiatry, 39(7), 850-858.

Kaiser, A. P., \& Hester, P. P. (1997). Prevention of conduct disorder trough early intervention: a social communicative perspective. Behavioral Disorders, 22(3), 177-130.

Keegstra, A. L., Post, W. J., \& Goorhuis-Brouwer, S. M. (2010). Behavioural problems in young children with language problems. International Journal of Pediatric Otorhinolaryngology, 74, 637-641.

Kerr, D.C.R., Lunkenheimer, E.S., \& Olson, S.L. (2007). Assessment of child problem behaviors by multiple informants: a longitudinal study from preschool to school entry. Journal of Child Psychology and Psychiatry, 48(10), 967-975.

Koot, H. M., van der Oort, E. J. C. G., Verhulst, F. C., \& Boomsma, D. I. (1997). Behavioural and emotional problems in young preschoolers: cross cultural testing of the validity of the Child Behavior Checklist/2-3. Journal of Abnormal Child Psychology, 25(3), 183-196.

Leung, P. W. et al. (2006). Test-retest reliability and criterion validity of the Chinese version of CBCL, TRF, and YSR. Journal of Child Psychology and Psychiatry, 47(9), 970-973.

Longstaffe, S., Moffatt, M. E. K., \& Whalen, J. C. (2000). Behavioral and Self-Concept Changes After Six Months of Enuresis Treatment: A Randomized, Controlled Trial. Pediatrics, 105(3), 925-940.

López-Soler, C., Sáez, M.C., Lopez, M.A., Fernández, V.F., \& Pina, J.A.L. (2009). Prevalencia y características de los síntomas externalizantes en la infancia: diferencias de género. Psicothema, 21(3), 353-358.

Luiz, A. M. A. G., Gorayeb, R., \& Liberato Jr, R. D. R. (2010). Avaliação de depressão, problemas de comportamento e competência social em crianças obesas. Estudos de Psicologia, 27(1), 41-48. 
Oncü, B., Oner, O., Oner, P., Erol, N., Aysev, A., \& Canat, S. (2004). Symptoms defined by parents' and teachers' ratings in attention-deficit hyperactivity disorder: changes with age. Canadian Journal of Psychiatry, 49(5), 487-491.

Oort, F. V. A., van der Ende, J., Wadsworth, M. E., Verhulst, F. C., \& Achenbach, T. M. (2011). Crossnational comparison of the link between socioeconomic status and emotional and behavioral problems in youths. Social Psychiatry and Psychiatric Epidemiology, 46, 167-172.

Pacheco, J., Alvarenga, P., Reppold, C.T., Piccinini, C.A., \& Hutz, C. (2005). Estabilidade do Comportamento Anti-social na Transição da Infância para a Adolescência: Uma Perspectiva Desenvolvimentista. Psicologia: Reflexão e Crítica, 18, 55-61.

Pedrini, J., \& Frizzo, G.B. (2010). Avaliação de indicadores de problemas de comportamento infantil relatados por pais e professores. Aletheia, 33, 69-83.

Petri, J. C. M. (2000). Reliability of Child Behavior Checklist for the assessment of behavioral problems of child and adult with mild mental retardation. Research in Developmental Disabilities, 21, 31-41.

Rescorla, L.A. (2005). Assessment of young children using the Achenbach system of empirically based assessment (ASEBA). Mental Retardation and Developmental Disabilities, 11, 226-237.

Rescorla, L. A., Achenbach, T. M., Ivanova, M. Y., Bilenberg, N., Bjarnadottir, G., Denner, S., ... Verhulst, F. C. (2012). Behavioral/Emotional Problems of Preschoolers: Caregiver/Teacher Reports From 15 Societies. Journal of Emotional and Behavioral Disorders, 20(2), 68-81.

Rocha, M. M., Rescorla, L. A., Emerich, D. R., Silvares, E. F. M., Borsa, J. C., Araújo, L. G. S., ... Assis, S. G. (2012). Behavioural/emotional problems in Brazilian children: findings from parents' reports on the Child Behavior Checklist. Epidemiology and Psychiatric Sciences, 22, 1-10.

Rosner, B. (1995). Fundamentals of biostatistics. 4th ed. Belmont, CA: Duxbury Press.

Sá, D. G. F., Curto, B. M., Bordin, I. A. S., \& Paula, C. S. (2009). Exposição à violência como risco para o surgimento ou a continuidade de comportamento antissocial em adolescentes da região metropolitana de São Paulo. Psicologia: Teoria e Prática, 11(1), 179-188.

Schneiders, J. et al. (2003). Neighbourhood socioeconomic disadvantage and behavioural problems from late childhood into early adolescence. Journal of Epidemiology E Community Health, 57, 699-703.

Silva, A. T. B. (2000). Problemas de comportamento e comportamentos socialmente adequados: sua relação com as habilidades sociais educativas de pais. 2000. Dissertação (Mestrado em Psicologia) - Universidade Federal de São Carlos, São Paulo.

Syed, E. U., Hussein, S. A., \& Mahmud, S. (2007). Screening for emotional and behavioural problems amongst 5-11-year-old school children in Karachi, Pakistan. Social Psychiatry and Psychiatric Epidemiology, 42, 421-427. 